\title{
Forthcoming
}

J Yorke (ed), Orientations of the Right and Value of Life, Farnham: Ashgate Publishing, 2010.

\section{Access to Medicines and the Right to (Cultural) Life}

\author{
Johanna Gibson $^{1}$
}

\section{Introduction}

Access to information and the right to participate in the benefits of scientific research and progress are instrumental in the achievement of high standards of health. This is important in terms of the goods available to individuals, including access to quality medicines. But it is also critical that individuals have access to adequate information delivered in a culturally relevant and meaningful context. Indeed, the significant relationship between development, poverty and health is crucial to understand in the broader context for health, including the right to development ${ }^{2}$ and the right to cultural life. ${ }^{3}$ The relationship between the cultural life of scientific research and progress and the human right to health is arguably fundamental, yet it receives perhaps less attention in the context of access to medicines than the more explicit negotiations of the right to the highest attainable standard of health. ${ }^{4}$ Furthermore, the delivery of the right to development rests upon cultural participation and health as essential components of development itself. For these reasons, it is not merely related to but rather it is critical to the characterisation of the right to health to examine the relationship with development and culture. In the context of debates in intellectual property protection and commercialisation, this chapter considers the right to access quality medicines as an element of the right to cultural life, including the right to participate in the benefits of scientific research.

The discourse on rights indicates a certain dichotomy between natural or 'moral' rights and economic rights. The latter is attended by more robust implementation and enforcement, premised and articulated upon binding legal statute. With the effects of

\footnotetext{
${ }^{1}$ Herchel Smith Professor of Intellectual Property Law, Queen Mary University of London.

${ }^{2}$ UN General Assembly. Resolution 41/128 Declaration on the Right to Development. A/RES/41/128. 4 December 1986.

${ }^{3}$ International Covenant on Economic Social and Cultural Rights (ICESCR), Article 15.

${ }^{4}$ ICESCR, Article 12.
} 
globalisation on legal systems and trading environments, economic rights become perhaps prioritised or interpreted as the totality of legal rights and indeed the "whole picture" with respect to models for innovation (including pharmaceutical innovation). Indeed, the democratisation of the public sphere is premised upon relationships in private property, upon the recognition and exercise of proprietary rights, and so the 'morality' of the legal system is rendered somewhat ancillary. Privileged discourses of 'freedom' and 'rights' come to be attached to private property and, as such, a principal authority is conferred upon the value of "property", including that prescribed by the intellectual property system.

Of critical importance to ensuring the access of individuals to public health, including the necessary opportunities for social well-being, development and cultural participation, is the communication of human rights principles within commercial systems: "human rights institutionalize the communicative conditions for a reasonable political will-formation." 5 Indeed, what is at stake is not the rendering of certain frameworks, like the patent system, as ethical frameworks, but rather it is the intervention of moral rationalism within legal discourse and towards sustaining its legitimacy. While the economic intellectual property system may be seen to allow for the privateering of the private sphere, it is necessary to examine the way in which the moral principles of the private sphere can be invigorating and legitimating forces in a functioning economic system: "[human rights] are constitutive for the legal order as a whole and to this extent determine a framework within which normal legislation must be conducted." 6 Therefore, as well as noting the basis in human rights for ensuring an individual's right to health and access to health care opportunities, it is necessary in the present discussion to consider further the circumstances by which to achieve the right to health, including cultural and political circumstances in accessibility and acceptability of health care.

\section{The Cultural Basis for Health}

The cultural and physical health and well-being of the individual underpins the full realisation of the right to cultural life, comprising the individual's access to the public sphere and to the institutions within that sphere, including the institution of medicine and health care. The ongoing cultural and legitimate constitution of that institution's normative and legal order indicates the role of access (more properly, the role of use) by the individual and the collective in its maintenance and reproduction.

The right to health, being a broad inclusive right to the circumstances necessary for physical as well as social and mental well-being, is fulfilled where there is meaningful

\footnotetext{
${ }^{5}$ Habermas J (2001/[1998]) The Postnational Constellation: Political Essays, Pensky M (trans \& ed), Cambridge, Polity P: 117.

${ }^{6}$ Habermas J (1998/[1996]) The Inclusion of the Other: Studies in Political Theory, Cronin C and de Greiff P (trans), Cambridge, Polity P: 190.
} 
access to and availability of health care goods and services. ${ }^{7}$ Thus, the full realisation of the right to health includes fulfilment of the underlying cultural, social and political determinants relevant to health. Not only is health thus a condition of fuller participation in cultural life, but also cultural participation and access to the benefits of cultural and intellectual life, persist as predetermining conditions of the fulfillment of the right to health. Therefore, the present discussion concentrates on the examination of this relationship between culture and health, in the context of the wider scholarship on the right to health and the relationship between health and development. If obligations to the fulfilment of individual rights with respect to health are met, then arguably this is the mechanism by which to overcome individual life chances. Robust protection of rights would provide the opportunity to access health and autonomy over the conduct of one's own life. Thus, rights must necessarily secure both the democratisation of the public sphere, ensuring access to the institution of health, and the morality and legitimacy of judgments and participation within that sphere. ${ }^{8}$

Jürgen Habermas explains that a democratic and political public sphere will be one where there is access to the necessary opportunities for participation and development. ${ }^{9}$ These are the necessary circumstances for the integrity of the individual: "Socialized individuals could not maintain themselves as subjects at all if they did not find support in the relationships of reciprocal recognition articulated in cultural traditions and stabilized in legitimate orders - and vice versa." ${ }^{10}$ That is, cultural and knowledge exchange reproduces individual integrity and control that may be guaranteed through access to production (that is, access to consumption of knowledge) and indeed reproduces the lifeworld itself. ${ }^{11}$ Again, the access to knowledge is critical to health not only in the immediate context of access to medicines but also in terms of the broader well-being and integrity of the individual. From the perspective of the patent as a private proprietary right, the relationship between property and the public sphere comes to the fore. If private property rights suggest the participation in the public sphere (the democratisation of the public sphere) then it is only when genuine accessibility is achieved that the right to health can be

\footnotetext{
${ }^{7}$ ICESCR Article 12; Committee on Economic Social and Cultural Rights (CESCR). General Comment No 14 (2000). The right to the highest attainable standard of health (Article 12 of the International Covenant on Economic, Social and Cultural Rights. $22^{\text {nd }}$ Session. E/C.12/2000/4. 11 August 2000.

${ }^{8}$ Habermas explains that there "are two tasks the required system of rights is supposed to solve. It should institutionalize the communicative framework for a rational political will-formation, and it should ensure the very medium in which alone this will-formation can express itself as the common will of freely associated legal persons." See Habermas J (1997/[1992]) Between Facts and Norms: Contributions to a Discourse Theory of Law and Democracy, Rehg W (trans), Cambridge, Polity P: 111.

9 Habermas J (1997/[1992]) Between Facts and Norms: Contributions to a Discourse Theory of Law and Democracy, Rehg W (trans), Cambridge, Polity P: 367.

${ }^{10}$ Habermas J (1997/[1992]) Between Facts and Norms: Contributions to a Discourse Theory of Law and Democracy, Rehg W (trans), Cambridge, Polity P: 80.

${ }^{11}$ Habermas J (2001/[1998]) The Postnational Constellation: Political Essays, Pensky M (trans \& ed), Cambridge, Polity P:152.
} 
understood as fully realised. And as a component of the right to cultural life, this accessibility to the services, goods and information necessary to health is not merely a personal interest but also an important aspect of the broader social benefit: "Only the rights of political participation ground the citizen's reflexive, self-referential legal standing. Negative liberties and social entitlements, on the contrary, can be paternalistically bestowed ... Historically speaking, liberal rights crystallized around the social position of the private property owner." 12

Indeed, health arguably has become less a condition of biology and more a condition of social status, ${ }^{13}$ that is, the 'life chances' of the particular individual:

It is the most elemental economic fact that the way in which the disposition over material property is distributed among a plurality of people, meeting competitively in the market for the purpose of exchange, in itself creates specific life chances ... the kind of chance in the market is the decisive moment which presents a common condition for the individual's fate. ${ }^{14}$

Representative of an economic and social class, life chances manifest in the opportunities for access to and possession of goods. ${ }^{15}$ These life chances therefore administer not only the individual's access to medicines but also the research agenda into diseases affecting certain populations and regions, in that the latter will be dominated by considerations of the profitability of markets. The ability to use creative material, to access medicines and to access educational material are all key issues demonstrating the conflict between the ordinary lives of citizens and the commercial system of intellectual property. The critical articulating factor is therefore access.

\section{Health and the Right to Culture}

Despite the central and critical role of the individual's and the community's socioeconomic and cultural conditions, the right to culture nevertheless has received considerably less attention in the context of health debates. Indeed its role in relation to the right to health is somewhat marginalised in the debates, some going as far as

\footnotetext{
12 Habermas J (1997/[1992]) Between Facts and Norms: Contributions to a Discourse Theory of Law and Democracy, Rehg W (trans), Cambridge, Polity P: 78.

${ }^{13}$ The 2008 WHO Report of the Commission on Social Determinants of Health (CSDH) reports on the inequities of access to health care as determined by social status rather than biological or physical environmental vulnerabilities to which a particular group may be subject. See WHO CSDH (2008), Closing the gap in a generation: Health equity through action on the social determinants of health. Geneva, World Health Organization.

${ }^{14}$ Weber develops the concept of life chances in Economy and Society, particularly Volume III. See Weber M (1968/[1956]) Economy and Society: An Outline of Interpretive Sociology, Roth G \& Wittich C (eds), New York, Bedminster P: 927-28.

${ }^{15}$ Weber M (1968/[1956]) Economy and Society: An Outline of Interpretive Sociology, Roth G \& Wittich C (eds), New York, Bedminster P: 927.
} 
suggesting that it is ancillary to the right to health. ${ }^{16}$ However, arguably its relevance in this area is much more significant and indeed it is an interpretive framework for the right to health itself. Article 15 of the ICESCR provides for the right to culture, broadly speaking:

1. The States Parties to the present Covenant recognize the right of everyone:

(a) To take part in cultural life;

(b) To enjoy the benefits of scientific progress and its applications;

(c) To benefit from the protection of the moral and material interests resulting from any scientific, literary or artistic production of which he is the author.

2. The steps to be taken by the States Parties to the present Covenant to achieve the full realization of this right shall include those necessary for the conservation, the development and the diffusion of science and culture.

3. The States Parties to the present Covenant undertake to respect the freedom indispensable for scientific research and creativity activity.

4. The States Parties to the present Covenant recognize the benefits to be derived from the encouragement and development of international contacts and cooperation in the scientific and cultural fields. ${ }^{17}$

The broader entitlements and freedoms within this right are importantly relevant to providing for equal opportunities for all citizens to take part in cultural life ${ }^{18}$ and enjoy the benefits of scientific progress, ${ }^{19}$ regardless of individual life chances. Significantly, this would indicate the right to access the benefits of medical research and development, including medicines. Further, it would also indicate the need for attention to possible obstacles to incentives to scientific research that may be posed by excessive intrusion of intellectual property monopolies. ${ }^{20}$

On the greater relevance of Article 15 to the right to health, the General Comment No 16 on the implementation of Article $3^{21}$ is important. Article 3 concerns equality of access for men and women to economic, social and cultural rights:

\footnotetext{
${ }^{16}$ For instance, see the discussion in Hestermeyer H (2007) Human Rights and the WTO: The Case of Patents and Access to Medicines, Oxford, OUP: 112.

${ }^{17}$ ICESCR, Article 15.

${ }^{18}$ Article 15.1(a).

${ }^{19}$ Article 15.1(b).

${ }^{20}$ For instance, consider the specific nature of patents for gene-related inventions, where the classical interpretation of patent protection may preclude further commercialisation of products for other uses based on the same gene sequence, and the relevance of purpose-bound protection in these areas. See further Gibson J (2009) Intellectual Property, Medicine and Health: Current Debates, Farnham: Ashgate Publishing (particularly chapters 2 and 6).

${ }^{21}$ CESCR. General Comment No 16(2005). The equal right of men and women to the enjoyment of all economic, social and cultural rights (art 3 of the International Covenant on Economic, Social and Cultural Rights). E/C.12/2005/4. 11 August 2005.
} 
The States Parties to the present Covenant undertake to ensure the equal right of men and women to the enjoyment of all economic, social and cultural rights set forth in the present Covenant. ${ }^{22}$

The significance of this right is that it is a "non-derogable standard for compliance with the obligations of States parties as set out in Articles 6 through 15 of ICESCR"23 and is of particular relevance to the access to health care and information in many developing countries. Further, the General Comment's approach to the eradication of discrimination and the promotion of equality of opportunities for all individuals to access economic, social and cultural rights is important. In particular, it takes account of discrimination both within the law and in a broader social context, citing failure to address the total context for the realisation of economic, social and cultural rights being a violation of those rights:

The principle of equality between men and women is fundamental to the enjoyment of each of the specific rights enumerated in the Covenant. Failure to ensure formal and substantive equality in the enjoyment of any of these rights constitutes a violation of that rights. Elimination of de jure as well as de facto discrimination is required for the equal enjoyment of economic, social and cultural rights. Failure to adopt, implement and monitor effects of laws, policies and programmes to eliminate de jure and de facto discrimination with respect to each of the rights enumerated in rights 6 to 15 of the Covenant constitutions a violation of those rights. ${ }^{24}$

In May 2008, during its $40^{\text {th }}$ Session, the CESCR organised a Day of General Discussion (DGD) on the right to take part in cultural life (Article 15.1(a)). A DGD is a public meeting open to international UN institutions, governments, intergovernmental organisations, non-governmental organisations (NGO) and civil society. The meeting on Article 15.1(a) structured discussions around four themes: the definition of cultural life within the human rights framework; analysing the right to cultural life itself and access to that right; exploring and identifying the interaction between the right to cultural life and other universal human rights; and the individual and collective character of the right. The last theme is particularly relevant in the context of discussions throughout this book of the need to interpret the full realisation of human rights through participation in the public sphere as an important aspect of the social formation of human collectives. In a background paper to the DGD, Elissavet

\footnotetext{
${ }^{22}$ ICESCR, Article 3.

${ }^{23}$ CESCR. General Comment No 16(2005). The equal right of men and women to the enjoyment of all economic, social and cultural rights (art 3 of the International Covenant on Economic, Social and Cultural Rights). E/C.12/2005/4. 11 August 2005. Paragraph 17.

${ }^{24}$ CESCR. General Comment No 16(2005). The equal right of men and women to the enjoyment of all economic, social and cultural rights (art 3 of the International Covenant on Economic, Social and Cultural Rights). E/C.12/2005/4. 11 August 2005. Paragraph 41.
} 
Stamtopoulou, Secretariat of the Permanent Forum on Indigenous Issues (PFII) welcomed the DGD, describing the right to participate as a neglected human right. ${ }^{25}$

Contributions by participants explored explicitly the link between the right to cultural life and the right to health. The International Commission of Jurists argued that health is in fact an aspect of cultural life, acknowledging the importance of cultural acceptability and relevance in the implementation and realisation of human rights throughout the work of the CESCR:

The right to participate in cultural life is closely connected with many other human rights. Some other human rights are particularly significant for the right to participate in cultural life ... However, the exercise of many other human rights also entails cultural components, relevant to assess the enjoyment of the right to take part in cultural life. The Committee on Economic, Social and Cultural Rights has adequately captured this concept in several of its General Comments referred to specific economic and social rights, through the notion of 'acceptability,' 'cultural adequacy' or 'cultural appropriateness.' The Committee has employed this notion to define the normative requirements of other rights set forth by the International Covenant on Economic, Social and Cultural Rights (ICESCR) - such as the right to adequate house, the right to adequate food, the right to the highest attainable standard of health and the right to water. This, in turn, implies that food, housing, health and water can be, inter alia, significant components of cultural life. ${ }^{26}$

Indeed, towards achieving accessibility to the right, Article 15.1(a) should be interpreted with respect for cultural relevance and acceptability. In particular, in the context of traditional medical knowledge, the right to cultural life is significant not only in terms of access to participate and practise traditional knowledge, but also in terms of achieving relevant protection for the holders of that knowledge, pursuant to Article 15.1(c). Traditional medicine is a particularly significant public health resource for many communities and regions in the world. ${ }^{27}$ With respect to medical research and public health, both the transfer of traditional medical knowledge in research and development as well as its cultural and social relevance to adequate health care in many regions raise the issue of the right to culture as it interacts with health.

A broader understanding of the importance of cultural specificity and relevance in delivering health care therefore will offer insight into the efficacy of primary health care. Indeed, sharing of benefits, delivery of public health care and access to medicines in traditional and indigenous communities directly implicates the importance of culture to medicine and medical systems. As well as the question of access to medicines in broader populations in developing countries, associated prevention and treatment must

\footnotetext{
${ }^{25}$ Stamatopoulou E (2008). The right to take part in cultural life. Background paper. Day of General Discussion on the right to take part in cultural life (article 15(1)(a) of the Covenant). E/C.12/40/9. 9 May 2008: page 2.

${ }^{26}$ International Commission of Jurists (2008). Background Paper. Day of General Discussion on the right to take part in cultural life (article 15(1)(a) of the Covenant). E/C.12/40/9. 9 May 2008: page 2. Emphasis added.

${ }^{27}$ WHO. Fact sheet No. 134. Traditional Medicine.
} 
be prepared and available within a respected and trusted infrastructure, which includes cooperation with traditional healers. The World Health Organization (WHO) traditional medicine strategy 2002-2005 outlines its main objectives with respect to traditional medicine, including the integration of traditional medicine in national health systems ${ }^{28}$ implementation of international standards and clinical guidelines and the facilitation of knowledge transfer. ${ }^{29}$

Current intergovernmental discussions towards the equitable management and benefit sharing of traditional knowledge and genetic resources are also immediately relevant to health and access to medicines in the community concerned. ${ }^{30}$ In particular, the critical social and cultural dimension to medicine and medical practice in many indigenous and traditional communities is significant to delivering culturally-relevant and effective health care (such as through collaborations between western and traditional practitioners) as well as fulfilling the cultural participation of the groups involved. Furthermore, the potential research and commercial value in genetic resources and associated traditional knowledge indicates the importance of developmental concerns in the context of the realisation of the right to health and the creation of frameworks within which to manage medicinal products and knowledge. Realisation of the right to health not only underpins development, but also the right to development and culture emerge as determining factors for health.

\section{The Right to Development}

The UN General Assembly adopted the Declaration on the Right to Development, by Resolution 41/128, in its $41^{\text {st }}$ Session, $1986 .{ }^{31}$ Article 1.1 declares the right to development to be an inalienable human right:

The right to development is an inalienable human right by virtue of which every human person and all peoples are entitled to participate in, contribute to, and enjoy

\footnotetext{
${ }^{28}$ Traditional medicine is also an important aspect of the full realisation of Article 12 of the ICESCR. See CESCR. General Comment No 14 (2000). The right to the highest attainable standard of health (article 12 of the International Covenant on Economic, Social and Cultural Rights. 22 ${ }^{\text {nd }}$ Session. E/C.12/2000/4. 11 August 2000: Paragraph 27

${ }^{29}$ World Health Organization (WHO) traditional medicine strategy 2002-2005.

${ }^{30}$ In particular, see the documents of the World Intellectual Property Organization (WIPO) Intergovernmental Committee in Intellectual Property and Genetic Resources, Traditional Knowledge and Folklore. For a full discussion of the cultural and legal conflicts between traditional knowledge and intellectual property frameworks, the work of WIPO and international initiatives towards protection, see Gibson J (2005) Community Resources: Intellectual Property, International Trade and Protection of Traditional Knowledge, Aldershot, Ashgate.

${ }^{31}$ UN General Assembly. Resolution 41/128 Declaration on the Right to Development. A/RES/41/128. 4 December 1986.
} 
economic, social, cultural and political development, in which all human rights and fundamental freedoms can be fully realized. ${ }^{32}$

This character of the right to development is articulated with respect to health in Article 8. Article 8.1 provides for health as one of the underlying determinants for the full realisation of the right to development:

States should undertake, at the national level, all necessary measures for the realization of the right to development and shall ensure, inter alia, equality of opportunity for all in their access to basic resources, education, health services, food, housing, employment and the fair distribution of income. ${ }^{33}$

In effect, the fulfilment of the right to development necessarily addresses the life chances of all citizens and provides for opportunities for all individuals to these fundamental human rights. As such, the Declaration also provides that the right to development necessarily supports the right to self-determination in Article 1.2, including the right to sovereignty over genetic resources:

The human right to development also implies the full realization of the right of peoples to self-determination, which includes, subject to the relevant provisions of both International Covenants on Human Rights, the exercise of their inalienable right to full sovereignty over all the natural wealth and resources.

Importantly, beyond the primary nature attributed to the value of property in democratic systems, the right to development and its implication of the right of selfdetermination articulate democracy upon principles of the collective. This is significant not only for human rights discourse but also for the social and political dimension of individual human rights as safeguarding the individual's opportunities to participate in the public sphere: "States should encourage popular participation in all spheres as an important factor in development and in the full realization of all human rights." 34

This resonates with earlier examinations of the importance of the individual's life chances and access to the public sphere. Habermas emphasises the communicative value of the law and the legitimating force of addressing the circumstances for that social cohesion. In other words, in addressing not only access, in terms of availability, but also use in terms of genuine participation, "governmental authority derives from the power produced communicatively in the civic practice of self-determination, and it finds its legitimation in the fact that it protects this practice by institutionalizing public

\footnotetext{
${ }^{32}$ UN General Assembly. Resolution 41/128 Declaration on the Right to Development. A/RES/41/128. 4 December 1986. Paragraph 1.1.

${ }^{33}$ UN General Assembly. Resolution 41/128 Declaration on the Right to Development. A/RES/41/128. 4 December 1986. Paragraph 8.1

${ }^{34}$ UN General Assembly. Resolution 41/128 Declaration on the Right to Development. A/RES/41/128. 4 December 1986. Paragraph 8.2
} 
liberty." ${ }^{35}$ The right to development articulates this 'use' of the public sphere as an inalienable human right and characterises the value of the fulfilment of that right to the social collective:

[D] evelopment is a comprehensive economic, social, cultural and political process, which aims at the constant improvement of the well-being of the entire population and of all individuals on the basis of their active, free and meaningful participation in development and in the fair distribution of benefits resulting therefrom ... everyone is entitled to a social and international order in which the rights and freedoms set forth in that Declaration can be fully realized. ${ }^{36}$

In 1993, the World Conference on Human Rights considered the right to development at length and adopted by consensus of the 171 Member States the Vienna Declaration and Programme of Action. ${ }^{37}$ Paragraph 10 of the Declaration "reaffirms the right to development, as established in the Declaration on the Right to Development, as a universal and inalienable right and an integral part of fundamental human rights." 38 Indeed, the right to development is inextricably and necessarily implicated in the realisation of fundamental human rights, ${ }^{39}$ including the human right to health ${ }^{40}$ and freedoms and entitlements contained within that human right. This includes access to benefits of scientific research and development as part of the meaningful fulfilment of the right to development, arguably incorporating access to medicinal products. Paragraph 11 provides that:

Everyone has the right to enjoy the benefits of scientific progress and its applications. The World Conference on Human Rights notes that certain advances, notably in the biomedical and life sciences as well as in information technology, may have potentially adverse consequences for the integrity, dignity and human

\footnotetext{
35 Habermas J (1997/[1992]) Between Facts and Norms: Contributions to a Discourse Theory of Law and Democracy, Rehg W (trans), Cambridge, Polity P: 270.

${ }^{36}$ UN General Assembly. Resolution 41/128 Declaration on the Right to Development. A/RES/41/128. 4 December 1986. Preamble. See further Paragraph 2.

${ }^{37}$ World Conference on Human Rights. Vienna Declaration and Programme of Action. A/CONF.157/23. 12 July 1993.

${ }^{38}$ World Conference on Human Rights. Vienna Declaration and Programme of Action. A/CONF.157/23. 12 July 1993. Paragraph 10. See further Paragraph 72 which declares that the right, as established in the Declaration on the Right to Development, must be implemented and realised. Further, the Declaration recommends the participation of civil society and NGOs in normative developments and cooperation with State Actors (Paragraph 38; Paragraph 73) and notes the necessary cooperation between actors in the field of development (Part C), compatible with the principles of cooperation for achievement of the MDGs. The relevance of civil society activity is considered further in Part IV: Access.

${ }^{39}$ World Conference on Human Rights. Vienna Declaration and Programme of Action. A/CONF.157/23. 12 July 1993. Paragraph 74.

${ }^{40}$ World Conference on Human Rights. Vienna Declaration and Programme of Action. A/CONF.157/23. 12 July 1993. Paragraph 31.
} 
rights of the individual, and calls for international cooperation to ensure that human rights and dignity are fully respected in this area of universal concern. ${ }^{41}$

The Vienna Declaration reaffirms the right of self-determination of all peoples in Paragraph 2 and explains its basis for the free pursuit of economic, social and cultural development. $^{42}$ This is related to Paragraph 20, which calls for the facilitation of indigenous peoples' full social, political and cultural participation:

The World Conference on Human Rights recognizes the inherent dignity and the unique contribution of indigenous people to the development and plurality of society and strongly reaffirms the commitment of the international community to their economic, social and cultural well-being and their enjoyment of the fruits of sustainable development. States should ensure the full and free participation of indigenous people in all aspects of society, in particular in matters of concern to them.

Again, the link between development and access to the public sphere is instrumental and fundamental to the full realisation of human rights, with self-determination being a critical mechanism through which to achieve development. The Vienna Declaration "recommends that priority be given to national and international action to promote democracy, development and human rights" 43 and thus "reaffirms that the universal and inalienable right to development, as established in the Declaration on the Right to Development, must be implemented and realized." 44

The open-ended Working Group on Development was established by the Commission on Human Rights by Resolution 1998/72 ${ }^{45}$ and the UN Economic and Social Council (ECOSOC) Decision 1998/269 $9^{46}$ to monitor and review progress on the implementation of the right at national and international levels for an initial period of 3 years. Pursuant to Commission on Human Rights Resolution 2004/7, the high-level task force on the implementation of the right to development was established. The high-level task force is a group of 5 experts nominated by the Chairperson of the Working Group, mandated by the Working Group to examine particular issues with respect to its objectives and subsequently provide technical expertise to the Working Group in its recommendations on implementation.

\footnotetext{
${ }^{41}$ World Conference on Human Rights. Vienna Declaration and Programme of Action. A/CONF.157/23. 12 July 1993. Paragraph 11.

${ }^{42}$ World Conference on Human Rights. Vienna Declaration and Programme of Action. A/CONF.157/23. 12 July 1993. Paragraph 2.

${ }^{43}$ World Conference on Human Rights. Vienna Declaration and Programme of Action. A/CONF.157/23. 12 July 1993. Paragraph 66.

${ }^{44}$ World Conference on Human Rights. Vienna Declaration and Programme of Action. A/CONF.157/23. 12 July 1993. Paragraph 72.

${ }^{45}$ Commission on Human Rights. Resolution 1998/72. The Right to Development.

${ }^{46}$ ECOSOC. Decision 1998/269. The Right to Development.
} 
The first meeting of the high-level task force was held in December 2004 with the mandate to examine two aspects of implementation: obstacles and challenges to the Millennium Development Goals (MDGs) ${ }^{47}$ in the context of the right to development; and national and international social impact assessments in trade and development. MDG 6 (to combat HIV/AIDS, malaria and other diseases) includes access to medicines as one of its explicit targets towards achieving this goal. ${ }^{48}$ MDG 8 (to develop a global partnership for development) includes the target to provide for access to affordable essential medicines for developing countries, by working in cooperation with pharmaceutical companies.

In its final report ${ }^{49}$ the task force identified "a holistic view of human rights" as underlying the Declaration on the Right to Development and agreed a series of 12 recommendations regarding implementation of the MDGs, including the recommendation to the Working Group to map the progress of the MDGs against existing human rights instruments. ${ }^{50}$ The second session considered MDG 8 in particular (global partnership for development) and agreed upon criteria for its periodic evaluation, which were subsequently adopted by the Working Group. The progress of these criteria was considered in the third session in 2007 and at the fourth session in 2008 these criteria and the progress of their application were reviewed and revised.

The fourth session deals at length with MDG 8 (develop a global partnership for development) and in particular Target 17 (access to affordable essential drugs in developing countries) which comes within the global partnership goal. ${ }^{51}$ Importantly,

47 At the 2000 UN Millennium Summit 189 UN Member States and at least 23 international organisations agreed to the Millennium Declaration (UN General Assembly. Resolution 55/2. UN Millennium Declaration. $51^{\text {st }}$ Session General Assembly, 18 September 2000). The Millennium Declaration establishes a set of 8 development goals to be achieved by 2015. These goals, known as the MDGs, include: the eradication of extreme poverty and hunger; the facilitation of universal access to and participation in primary education; the promotion of gender equality; the alleviation of child mortality; improve maternal health; the escalation of the campaign against HIV/AIDS, malaria and other diseases; ensure environmental sustainability; and the development of global partnerships towards development. Within each goal certain targets have been established to indicate progress towards achievement of the development programme. See further the discussion of the Millennium Development Goals (MDGs) and the targets defined within the 8 MDGs in Gibson J (2009) Intellectual Property, Medicine and Health: Current Debates, Aldershot: Ashgate (particularly chapter 3).

${ }^{48}$ This target includes the achievement of universal access to HIV/AIDS treatment by 2010 and securing access to antiretroviral drugs for a proportion of the population with advanced HIV infection.

${ }^{49}$ Commission on Human Rights. $61^{\text {st }}$ Session. Review of Progress in the Promotion and Implementation of the Right to Development: Consideration of the Report of the High-Level Task Force on the Implementation of the Right to Development. Report of the high-level task force on the implementation of the right to development. E/CN.4/2005/WG.18/2. 24 January 2005.

${ }^{50}$ Report of the high-level task force on the implementation of the right to development. E/CN.4/2005/WG.18/2. 24 January 2005. Paragraph 45.

${ }^{51}$ A full list of the goals and the targets comprising each goal in the Annex to the Road map towards the implementation of the United Nations Millennium Declaration, UN General Assembly, $56^{\text {th }}$ Session, 6 September $2001(\mathrm{~A} / 56 / 326)$. 
this target demonstrates the inextricable relationship between health and development, the link being explicit not only in the agreement on this Target but also in the commentary on the relevant achievement of the MDGs. Towards advancing progress on Target 17, the task force has resolved to conduct two working sessions: the first concerned with procurement and pricing, including multilateral frameworks and public-private initiatives; and second to deal with trade-related aspects of intellectual property rights under the World Trade Organization (WTO) system and the bilateral system of free trade agreements (FTA):

The task force proposes to examine the role of key multilateral and public-private initiatives in implementing Target 17 relating to access to affordable essential drugs in developing countries. This dialogue would involve partnerships focused on procurement and pricing as well as on trade-related aspects of intellectual property protection in the WTO and bilateral and regional free trade agreements involving relevant institutions. ${ }^{52}$

Similarly, the task force recommends work with the WHO and other relevant institutions towards the advancement of MDG Target 17, acknowledging the importance of the UN Special Rapporteur's draft Human Rights Guidelines for Pharmaceutical Companies in relation to Access to Medicines. ${ }^{53}$

\section{The World Health Organization}

At the Ninth Session of the open-ended Working Group, held in Geneva in August 2008, the Working Group mandated the task force to "give priority to the issue of access to essential medicines in developing countries (Target 8.E),"54 and to do so through a review of the work of the WHO Intergovernmental Working Group on Public Health, Innovation and Intellectual Property (IGWG). The IGWG was established in 2006 by resolution WHA 59.24 $4^{55}$ at the $59^{\text {th }}$ World Health Assembly (WHA) of the WHO. The IGWG was given a mandate to develop and prepare a global strategy and work programme, with particular regard to the special issues for developing countries.

\footnotetext{
${ }^{52}$ Human Rights Council. $8^{\text {th }}$ Session. Report of the high-level task force on the implementation of the right to development in its fourth session. A/HRC/8/WG.2/TF/2. 31 January 2008. Paragraph 85(a).

${ }^{53}$ UN Special Rapporteur on the right of everyone to the enjoyment of the highest attainable standard of physical and mental health. Human Rights Guidelines for Pharmaceutical Companies in relation to Access to Medicines. Draft for Consultation. 19 September 2007.

${ }^{54}$ Human Rights Council. Report of the Working Group on the Right to Development on its Ninth Session. A/HRC/9/17. 4 September 2008.

${ }^{55}$ WHA. Resolution WHA59.24. Public health, innovation, essential health research and intellectual property rights: towards a global strategy and plan of action. 27 May 2006.
} 
Following the report of the IGWG, at the $61^{\text {st }}$ WHA in 2008 the meeting adopted the Global strategy and Plan of Action by resolution, ${ }^{56}$ reaffirming the right to health as a fundamental right and prioritising the importance of addressing the health needs of developing countries in the research and development agenda of developed countries. Furthermore, the promotion of research and development is understood to include not only support to governments in the development of national programmes, but also the promotion of accessibility to research benefits in order to build capacity and innovation in developing countries. Mechanisms by which to achieve this advocated in the global strategy include open-source methods and the identification of incentives and barriers to research and development, including intellectual property. ${ }^{57}$ Access to knowledge and technology is emphasised throughout the strategy and includes mechanisms both within the intellectual property system (such as patent pools ${ }^{58}$ ) and through competition to improve availability and accessibility of products.

In establishing the IGWG, Resolution WHA 59.24 emphasises critical issues in global health in the context of the freedom to participate in the cultural life of the community and characterises the broader context in which the right to health is realised, also reflected in the global strategy ultimately adopted by the WHA. This broader context includes concerns related to pricing and access to medicines and the need for new models and initiatives to encourage and promote innovation. This is an important articulation of the interaction between various human rights and the critical question of social, cultural and political access. ${ }^{59}$ In this context, the resolution links questions of access and public health to the underlying determinants for public health, including the commercial environment in that the WHA urges Member States:

\footnotetext{
${ }^{56}$ WHA. Resolution WHA61.21. Global strategy and plan of action on public health, innovation and intellectual property. 24 May 2008: Element 1.

57 Element 2 of the Global Strategy and Plan of Action includes "promoting upstream research and product development in developing countries" a component of which includes the support of scientific research capacity and discovery including, "where feasible and appropriate, voluntary open-source methods." See Global Strategy and Plan of Action on Public Health, Innovation and Intellectual Property, adopted at the $59^{\text {th }}$ Session of the World Health Assembly by Resolution WHA61.21, 24 May 2008.

${ }^{58}$.A patent pool is a consortium of at least two companies agreeing to cross-license patents relating to a particular technology, often introduced as a measure between competitors to avoid infringement and litigation. Therefore, a patent pool can also create a monopoly over certain technology if competitors cooperate in such a way (and cross-license rather than sue for infringement or revocation of weak patents). As a result, competition issues can become very important when a large consortium or 'cartel' is formed. As a business model, patent pools are not new but have been relevant throughout the modern patent system. More recently, patent pooling has been advocated as a mechanism to promote generic competition in markets for essential medicines, thus lowering prices and also promoting access to research resources for ongoing drug development and improvement (addressing both issues of cost and production). In particular, the patent pool is advocated as an incentive and mechanism by which to stimulate innovation, simplifying the legal obstacles to access and pooling 'expertise' and establishing global norms in collective management and open competition.

${ }^{59}$ WHA. Resolution WHA59.24. Public health, innovation, essential health research and intellectual property rights: towards a global strategy and plan of action. 27 May 2006: Preamble.
} 
(1) to make global health and medicines a priority sector, to take determined action to emphasize priorities in research and development addressed to the needs of patients, especially those in resource-poor settings, and to harness collaborative research and development initiatives involving disease-endemic countries;

(2) to consider the recommendations of the report and to contribute actively to the development of a global strategy and plan of action, and to take an active part, working with the Secretariat and international partners, in providing support for essential medical research and development;

(3) to work to ensure that progress in basic science and biomedicine is translated into improved, safe and affordable health products - drugs, vaccines and diagnostics - to respond to all patients' and clients' needs, especially those living in poverty, taking into account the critical role of gender, and to ensure that capacity is strengthened to support rapid delivery of essential medicines to people;

(4) to encourage trade agreements to take into account the flexibilities contained in the Agreement on Trade-Related Aspects of Intellectual Property Rights and recognized by the Doha Ministerial Declaration on the TRIPS Agreement ${ }^{60}$ and Public Health ... ${ }^{61}$

The holistic approach to human rights advocated throughout the documents on development indicates that the right to culture should be considered in the context of intellectual property and health. Indeed, it is through the interrogation of human rights frameworks that the cultural life of patents is becoming particularly clear.

\section{Intellectual Property and the Right to Cultural Life}

The relationship between cultural relevance and legitimacy becomes clearer in this context. Legitimacy is derived from a system that is actually meaningful to the development of national industry and technical expertise, as distinct from the illegitimacy of a system that appears to promote external interests over and above those subjects to which the law is to apply. In this way, local expertise and consultation is crucial to the implementation of law so as to motivate legitimacy and promote national interests. Thus, there is a clear relationship between use and the creation of a beneficial interest in the resources and benefits of scientific and medical research and development; that is, in the full realisation of an individual's right to cultural participation or cultural life. In the context of access to the benefits of scientific research, that use necessitates the safeguarding of the beneficial enjoyment of

\footnotetext{
${ }^{60}$ The WTO Agreement on Trade-Related Aspects of Intellectual Property Rights (TRIPS).

${ }^{61}$ WHA. Resolution WHA59.24. Public health, innovation, essential health research and intellectual property rights: towards a global strategy and plan of action. Paragraph 2.
} 
scientific research as distinct from any legal rights created in those benefits through intellectual property systems.

This central value of use is critical to questions of morality in the application and exercise of patent law. When examining the concept of use in patent rights, not only the scope of the patent (the legal rights in the invention) but also the accessibility for users (the beneficial interests in the invention) will be manifest. This characterisation of use is furthermore critical to an appreciation of the cultural life of patents and provides a foundation for maintaining access to the beneficial interest in the invention, on behalf of the whole of society. In other words, the exercise of the legal rights in the patent should therefore be subject to obligations to the beneficial interests in the patent. Following this argument, failure to fulfil the equitable interests may thus compromise the ability to enjoy the legal rights. The invention is, in other words, held in trust - that is, both legal and equitable interests are held in the one property. This forms the basis of modern personal equitable obligations to deal with property for the benefit of another class of persons (that is, a beneficial interest other than the legal interest of the owners) - a type of 'Global Medicines Trust.' 62

Thus, while the goods comprising the resources necessary to the realisation of the right to health might incorporate private property interests (in the form of the patent), the knowledge contained within those goods might be seen as held in equitable trust to which all are entitled as beneficiaries under Article 15.1(b) of the ICESCR. Therefore, although the private property holder has certain legal rights to the invention defined within the patent, the invention itself is a public good. In principle, this can be interpreted as a beneficial interest in the invention held by each individual. In other words, there are two simultaneous interests in an invention - one is the legal interest defined by the patent; the other is the equitable interest in the invention as a public good.

Where the rights in the patent interfere with the beneficial interest in the public good to such an extent that the human right to health and to enjoy the applications of scientific research are compromised, then it must be possible to address this. That is, where the exercise of those rights begins to pose real and material obstacles to the capacity of governments to fulfil the right to health, then there may be a right against the 'trustee.' This human rights qualification on the exercise of trade-related intellectual property rights is found not only in instruments towards the interpretation and application of the right to health, ${ }^{63}$ but also in instruments concerning the full implementation of the right to development ${ }^{64}$ and in the TRIPS Agreement itself. Article 8 provides:

\footnotetext{
${ }^{62}$ This concept is dealt with in greater detail in Gibson J (2009) Intellectual Property, Medicine and Health: Current Debates, Farnham: Ashgate Publishing.

${ }^{63}$ OHCHR/UNAIDS (2006). International Guidelines on HIV/AIDS and Human Rights: Paragraph 52, Page 48.

${ }^{64}$ Commission on Human Rights. $61^{\text {st }}$ Session. Review of Progress in the Promotion and Implementation of the Right to Development: Consideration of the Report of the High-Level Task Force on the Implementation of the Right to Development. Report of the high-level task force on the implementation of the right to development.
} 
1. Members may, in formulating or amending their laws and regulations, adopt measures necessary to protect public health and nutrition, and to promote the public interest in sectors of vital importance to their socio-economic and technological development, provided that such measures are consistent with the provisions of this Agreement.

2. Appropriate measures, provided that they are consistent with the provisions of this Agreement, may be needed to prevent the abuse of intellectual property rights by right holders or the resort to practices which unreasonably restrain trade or adversely affect the international transfer of technology. ${ }^{65}$

Indeed, it is contended in this chapter that the law itself already recognises this beneficial interest of the public in the invention in the form of provisions for compulsory licensing. While the limitations imposed upon compulsory licensing by the TRIPS Agreement ${ }^{66}$ have been criticised, ${ }^{67}$ arguably the public health amendment to TRIPS goes a significant way to redress this. ${ }^{68}$ That is, where the beneficial interest is obstructed by the exercise of the legal interest, the balance is addressed by compulsory licensing. The central value of the trust, as it were, is that of use. Use not only constitutes the possessory relationship to knowledge, but also is the mechanism by which to fulfil the trust. That is, use constrains the legal rights; use contains the equitable interests.

Despite the 'crisis' in access and the creation of limitations on the benefits of these institutions, intellectual property and medicine and health care themselves are arguably, importantly and necessarily public goods rendered excludable by specific technical, but not consensual, intrusions. Therefore, the patent system takes nonexcludable knowledge and produces an excludable good (as an alternative to protecting one's invention by secrecy). It creates, therefore, legal rights in the invention that

E/CN.4/2005/WG.18/2. 24 January 2005: Paragraph 45. See further Human Rights Council. $8^{\text {th }}$ Session. Report of the high-level task force on the implementation of the right to development in its fourth session. A/HRC/8/WG.2/TF/2. 31 January 2008. Paragraph 85(a).

${ }^{65}$ TRIPS Article 8.

${ }^{66}$ Article 31.

${ }^{67}$ In relation to pharmaceuticals see Bass NA (2002) "Implications of the TRIPS Agreement for Developing Countries: Pharmaceutical Patent Laws in Brazil and South Africa in the $21^{\text {st }}$ Century" 34 George Washington Law Review 191. See generally Carvalho NP de (2005) The TRIPS Regime of Patent Rights, Hague, Kluwer Law International: 147-54; and Correa C (1999) Intellectual Property Rights, the WTO and Developing Countries: The TRIPS Agreement and Policy Options, London, Zed Books.

${ }^{68}$ Article 31 bis (the public health amendment) implements the Decision on Paragraph 6 of the Doha Declaration, waiving the obligations of TRIPS members to manufacture under a compulsory licence for the domestic market only, as provided under Article 31(f). Without this waiver, Article 31(f) posed a significant limit to the amount of generic product that could be exported when manufactured under a compulsory licence. Because of the limitation to the domestic market, this restriction limits the possible supply to countries unable to manufacture under compulsory licence themselves in times of national emergency. The Decision made it possible, within the terms set out in the Decision itself, for any member country to export generic product made under a compulsory licence. 
subsist alongside beneficial interests in the diffusion of that technology. Access to these institutions therefore underlies an individual's right to cultural life, not only in terms of the accessibility to the benefits of those institutions but also in terms of the use of those benefits for all regardless of individual life chances. Similarly, as a public good, the research and development that inputs into the institution of medicine and health care comprises not only the economic functioning of that institution but also the cultural life. Therefore, the cultural life of patents comprises not only the research culture that produces the resources of the institution of medicine, but also the ethical oversight for medicines (including both the ethical context for patents and the regulatory framework for medicines).

Therefore if private property rights suggest the participation in the public sphere (the democratisation of the public sphere) then it is only when genuine accessibility is achieved that the right to health can be understood to be fully realised. And as a component of the right to cultural life, this accessibility to the services, goods and information necessary to health is not merely a personal interest but an important aspect of the broader social benefit: "Only the rights of political participation ground the citizen's reflexive, self-referential legal standing. Negative liberties and social entitlements, on the contrary, can be paternalistically bestowed ... Historically speaking, liberal rights crystallized around the social position of the private property owner." 69

Use, in this context, generates the relationship of possession in the sense of historical relationships to land. During the period of feudal law, land could not be devised by will. ${ }^{70}$ Rather, it was held in strict feudal incidents of tenure whereby relationships to land were constructed in a hierarchy of obligations between vassals and lords. The 'use' was developed in order to overcome the rule as to divestiture by will. In this way, use constitutes 'ownership' and authority with respect to the land. This is of particular interest in the context of the contemporary model of western democracy modelled on private property rights. That is, use, in the fuller sense, appropriates this proprietary language and is part of the underlying mechanism for realisation of the right to cultural life. The right to cultural life incorporates participation through use.

\section{Conclusion}

The right to health is importantly and meaningfully an element of the full realisation of the right to cultural participation - not only in terms of the access to the benefits of scientific research ${ }^{71}$ but also in the broader sense of the right to cultural life. ${ }^{72}$

\footnotetext{
${ }^{69}$ Habermas J (1997/[1992]) Between Facts and Norms: Contributions to a Discourse Theory of Law and Democracy, Rehg W (trans), Cambridge, Polity P: 78.

${ }^{70}$ See further the discussion in Gray K \& Gray SF (2005) Elements of Land Law, Oxford, OUP: 92. For greater detail see Simpson AWB (1986) A History of The Land Law, $2^{\text {nd }}$ ed, Oxford, OUP.

${ }^{71}$ ICESCR Article 15.1(b).
} 
Incorporating both physical and mental well-being, the definition of health not only includes cultural identity but also relies upon attention to cultural diversity in its very interpretation and realisation, as embodied in the element of 'acceptability. 73 Therefore, the full realisation of the right to health derives from more than mere entitlement to access. It necessarily comprises the four principles of the right, which arguably constitute the fuller concept of 'use.' Importantly, participating in this public sphere and within this logic of the proprietary model of democracy and freedom, fulfilling use also fulfils the basis for 'possession' in a sense of meaningful and accessible use and benefit. The opportunity to use accounts for differences in life chances and addresses the genuine value upon which the western model of democracy is articulated. Use thus fulfils 'ownership,' that is, the political participation of individuals regardless of individual life chances. Meaningful access to medicines is fundamentally a question of the right to life.

\footnotetext{
${ }^{72}$ ICESCR Article 15.1(a).

${ }^{73}$ CESCR. General Comment No 14 (2000). The right to the highest attainable standard of health (article 12 of the International Covenant on Economic, Social and Cultural Rights. 22 ${ }^{\text {nd }}$ Session. E/C.12/2000/4. 11 August 2000. Paragraph 12.
} 